KS. LESZEK MISIARCZYK* - WARSZAWA

\title{
ZAPISKI O CUDACH Z 1148 ROKU W BIBLII PLOCKIEJ
}

Tekst zapisków wraz z krótkim komentarzem został wydany przez Z. Kozłowską-Budkową ${ }^{1}$, co należy uznać za niewątpliwą zasługę badaczki, gdyż jest to nadal pierwsze $i$ jedyne jego wydanie ${ }^{2}$. Jednak ze względu na fakt, że posiadała ona do dyspozycji zapewne słabej jakości zdjęcia, odczytany przez nią tekst zawiera kilka błędów. Przy dzisiejszych możliwościach technicznych, gdy zdjęcia i skany kodeksów można powiększać do dużych rozmiarów i dokładniej je odczytać, nowe, poprawione wydanie tych zapisków staje się koniecznością. Zostały one przetłumaczone na język polski po raz pierwszy przez arcybiskupa A.J. Nowowiejskiego $\mathrm{w}$ jego monumentalnej monografii o Płocku jeszcze w latach 30 . XX wieku, ale dzisiaj język tego tłumaczenia brzmi archaicznie i domaga się uwspółcześnienia. Te dwa motywy zachęciły mnie do nowego odczytania i wydania zapisków wraz z nowym ich thumaczeniem na język polski oraz krótką analizą w nadziei, iż przyczynią się one do dalszych badań nad kulturą i historią średniowiecza w Płocku i na Mazowszu.

M. Bershon w swoim monumentalnym dziele pt. Księgozbiór katedry płockiej, Warszawa 1899, jako jeden z pierwszych badaczy zajął się opisaniem średniowiecznych kodeksów zachowanych w Płocku. Tytuł jednak mylnie sugeruje, że przedstawił on charakterystykę wszystkich kodeksów jakie zachowały się w grodzie Hermana, podczas gdy tak naprawdę opisał w miarę szczegółowo tylko pięć: Pismo Święte określane dzisiaj Biblia Płocka z XII wieku, Missale Vetus, Graduat z XVI wieku, Liber revelationum beate Brygitte i Graduat z 1365 roku. Dla potrzeb niniejszego opracowania interesuje nas tutaj głównie tzw. Biblia

* Ks. Leszek Misiarczyk - dr hab. historii, profesor w Instytucie Nauk Historycznych UKSW w Warszawie, e-mail: 1.misiarczyk@uksw.edu.pl

${ }^{1}$ Z. Kozłowska-Budkowa, Płockie zapiski z 1148 r., „Roczniki Humanistyczne”, 44 (1930) s. 341-348.

${ }^{2}$ D. Brzeziński, B. Leszkiewicz, Zapiski liturgiczne w kodeksie Biblii Płockiej z XII wieku. Studium źródłoznawcze i edycja tekstu, Płock 2005 jak sami zaznaczają na s. 6 dołączyli edycję Z. Kozłowskiej-Budkowej nie odczytując na nowo tekstu. 
Płocka i to nie cała, a jedynie słynne zapiski w niej zawarte z roku 1148. Bershon tak charakteryzował te zapiski:

W roku 1148 w katedrze płockiej stały się głośnymi dwa cudy, które niewiadomy pisarz księgi jako naoczny świadek opisuje na karcie 138 pozostawionej początkowo w tekście Pisma Świętego próżną. Rozpoczyna się on od wyrazów „Anno Incarnationis Millesimo CXLVIII, gdy na stolicy papieskiej zasiadał Eugeniusz, gdy Cesarzem był Konrad, gdy w Polsce panowali: Bolesław (Kędzierzawy) Myscon (Mieczysław Stary), Henricus (Sandomierski), gdy biskupem Płockim był Aleksander et. etc" - poczem następuje opis cudu; drugi cud pod tymże rokiem opisuje również szczegółowo, więc widzimy, że Pismo Święte było własnością już obecnej katedry, po nowem jej wybudowaniu w r. 1136 przez biskupa Płockiego Aleksandra ze Szreńska, herbu Dołęga, w miejsce spalonego drewnianego kościoła Najświętszej Maryi Panny Mazowsza33.

Oprócz fałszywej informacji opartej na Długoszu o pochodzeniu biskupa Aleksandra z polskiego rodu Dołęgów a nie z kraju Mozy (dzisiejsza Belgia), Bershon czyni kilka uwag bardzo ważnych dotyczących naszych zapisków. Po pierwsze, opisane zostały dwa cuda, po drugie, ich autorem jest nieznany pisarz księgi, który był ich naocznym świadkiem, po trzecie, opis został dokonany na karcie 138, która wcześniej zostałaby pozostawiona pusta i wreszcie po czwarte, zapiski potwierdzają wyraźnie, że Pismo Święte było już w tym czasie własnością wcześniej wybudowanej przez biskupa Aleksandra, katedry w Płocku. Nie wiemy na jakiej podstawie autor twierdził, że zapiski znajdują się na karcie 138v, choć kodeks nie ma numeracji kart, zaś z później dopisanej ołówkiem numeracji wynika, że jest to karta 239v na którą został naniesiony dodatkowo ołówkiem numer 249. Ta późniejsza numeracja kart kodeksu jest również bardzo dziwna, gdyż wcześniejsza karta nosi numer 239, następna 240 a numer 249 pojawia się jako jedyny na $239 \mathrm{v}$, choć zazwyczaj numeracja jest umieszczona na stronie recto kart. Wygląda na to, że numeracja podana przez Bershona jest po prostu błędna. Dalej, według wspomnianego badacza zapiski umieszczone są na karcie, która była wcześniej pusta. Na karcie 238r kończy się bowiem Ewangelia według św. Jana (Explic[it] Euu[ange]l[iu]m s[e]c[undu]m Ioh[ann]em) a po niej na tej samej karcie znajdujemy tekst In caena domini lectio IIII de sermone beati augustini ep [iscopi], który jest kontynuowany na kartach 238v-239r. Następnie pojawiają się na karcie 239v nasze zapiski w lewej kolumnie i na początku kolumny prawej (6 wierszy), natomiast dalej, czyli karcie 239v w dalszej części kolumny prawej, całej kolumnie lewej i do połowy na karcie 240r znajduje się opis liturgii w katedrze płockiej ${ }^{4}$. Dalsza część kolumny prawej i cały foliał 240v jest pusty. Z kolei dalej, na karcie 241r rozpoczyna się Prolog św. Hieronima do Listów św. Pawła Apostoła. Jeśli Bershon ma rację i karty $239 \mathrm{v}$ oraz $240 \mathrm{r}-\mathrm{v}$ zostałyby rzeczywiście pozostawione puste, to nasze zapiski zostałyby dopisane później niż cały kodeks Pisma Świętego. Wtedy należy przypuszczać, że cały kodeks powstałby przed 1148 roku, a zapiski zostałyby dodane właśnie w tym roku jak same o tym mó-

${ }^{3}$ M. Bershon, Księgozbiór katedry płockiej, Warszawa 1899, s. 14-15 (pisowania oryginalna).

${ }^{4}$ Odczytany i wydany przez D. Brzeziński, B. Leszkiewicz, Zapiski liturgiczne w kodeksie Biblii Płockiej z XII wieku. Studium źródłoznawcze i edycja tekstu, Płock 2005, s. 27-34. 
wią albo bardzo krótko po tych wydarzeniach. Nie można jednak wykluczyć, że obydwa cuda wydarzyły się w trakcie spisywania kodeksu i wtedy skryptor dokonałby ich zapisu. Teoretycznie możliwe jest, że zostawiano puste karty w tego typu kodeksach biblijnych, aby oddzielić np. Stary Testament od Nowego albo jak w naszym przypadku, Ewangelie od Listów św. Pawła. W naszym kodeksie nie znajdujemy jednak wolnych kart np. pomiędzy Starym a Nowym Testamentem, ani w żadnym innym miejscu. Wyjątek stanowi karta $202 \mathrm{v}$, ale na niej na ok. $1 / 4$ jej części znajduje się mniatura, natomiast $\mathrm{w}$ całym zachowanym kodeksie, dodajmy niekompletnym, bo rozpoczyna się od księgi proroka Izajasza a kończy na Liście do Hebrajczyków, tylko tutaj mielibyśmy karty puste. Wydaje się to więc mało prawdopodobne. Zastanawiający jest również brak tekstu Dziejów Apostolskich po Ewangeliach, a przed Listami św. Pawła a obecność pomiędzy nimi właśnie naszych zapisków o cudach i potem opis liturgii katedralnej. Nie ulega wątpliwości, że kodeks jest niekompletny i być może w późniejszych stuleciach został wręcz pozbawiony oryginalnej kolejności ksiąg i np. Dzieje Apostolskie, choć pierwotnie należały do niego, gdzieś zaginęły. Warto zauważyć jednakże, że tekst o cudach i liturgii katedralnej nie został zapisany na marginesie kodeksu, jak to się niekiedy błędnie przedstawia $\mathrm{w}$ opracowaniach, ale w dwóch kolumnach, podobnie jak tekst ksiąg biblijnych przed nimi i po nich. Arcybiskup A.J. Nowowiejski w swojej monografii Płock. Monografia historyczna, Płock 1930 jest również zdania, że notatka pochodzi z czasów biskupa Aleksandra z Malonne i jak wspomniałem, podaje jej polskie tłumaczenie ${ }^{5}$. Wszystkie te opinie nie są jednak poparte żadnymi argumentami.

Zapiski o cudach zostały zapisane przez tego samego skryptora, lecz innym charakterem pisma niż cały kodeks, natomiast liturgia stylem podobnym do reszty kodeksu. Możliwe zatem są tutaj trzy rozwiązania ${ }^{6}$ :

1. kodeks powstał w 1148 roku i później dodano zapiski o cudach

2. kodeks powstawał w tym samym czasie, kiedy wydarzyły się cuda i w miejscu do którego doszli skrybowie w jego spisywaniu dołączono notatki o cudach 3. kodeks powstał później i zapiski również dodano później

Nie wykluczone więc, że zapiski o cudach i opis liturgii zostałyby dodane już $\mathrm{w}$ trakcie sporządzania kodeksu. W każdym razie cały kodeks powstałby w 1148 roku lub około tej daty, a żywy charakter opisu cudów zdaje się wskazywać, że zapiski powstały niedługo po samych wydarzeniach, czyli po 15 sierpnia 1148 roku lub na początku 1149 roku.

Zapis pierwszego cudu o uzdrowieniu kobiety imieniem Wojucha rozpoczyna się i kończy na f. 239v od góry w lewej, zewnętrznej kolumnie i zawiera 27 wierszy. W odczytywaniu tekstu w nawiasach kwadratowych [] umieszczone zostały te jego partie, które zostały zapisane skrótami i są moim odczytem. Natomiast w edycji tekstu zastosowano zasady opracowane przez A. Wolfa ${ }^{7}$ zachowując ory-

${ }^{5}$ A.J. Nowowiejski, Płock. Monografia historyczna, Płock 1930, s. 38-39.

${ }^{6}$ Por. Brzeziński, Leszkiewicz, Zapiski liturgiczne w kodeksie Biblii Płockiej z XII wieku, s. 11.

${ }^{7}$ A. Wolf, Projekt instrukcji wydawniczej dla źródet pisanych do połowy XVI wieku, „Studia Źródłoznawcze", 1 (1957) s. 155-181. 
ginalna ortografię i pisownię wielkimi literami oraz rozróżnienie pomiędzy literami „u” i „,v" oraz ,ii” i ,íl” a także „y” i ,ý”.

Tekst łaciński pierwszego cudu:

ANNO ab INcaRNaTIONE d[omi]Ni. Mill[esimo]

C. XLVIII. epacta. XXVIII.

C[ON]CURRENTE. IIII ${ }^{8}$ INdictio[n]e

XI . ANNO c [om]muni, ${ }^{9}$ PResidente Ro

me papa EvgeNio. ${ }^{10}$ Imperante cun

rado, ${ }^{11}$ IN Polonia aute[m] regnantib[us]

Bolezlao $^{12}, \mathrm{MyscoNe}^{13}$ et hinrico ${ }^{14}$,

fugato $\mathrm{q}[\mathrm{ue}]$ de terra Wlodizlao ${ }^{15}, \mathrm{p}[\mathrm{ro}]$

curante uero plocensem dioce

sim uenerabilis uite Alexandro

ep[iscop]o; beata Maria Virgo in die glo

rissim[a]e assumtionis su[a]e. ${ }^{16}$ presente

custode. azone. in eccl[es]ia plocensi

ante primam; iuuencula[m] contrac

tam. et semipede $[\mathrm{m}]$. dignata est $\mathrm{t}^{17}$ eri

gere et penitus sanare. $\mathrm{Cu}[\mathrm{m}] \mathrm{q}[\mathrm{ue}] \mathrm{ru}$

mor tanti miraculi ad aures serenis

$\mathrm{si}^{18}$ ducis Bolezlai qui tunc in castro

aderat $\mathrm{p}[\mathrm{er}] \mathrm{uenisset}$. uiro $\mathrm{q}[\mathrm{ue}] \mathrm{s}[\mathrm{an}] \mathrm{c}[\mathrm{t}] \mathrm{o} \mathrm{p}[\mathrm{re}]$ fato

$\mathrm{ep[iscop]o} \mathrm{Alexandro} \mathrm{iuuenculam.} \mathrm{Woyu}$

${ }^{8}$ Z. Kozłowska-Budkowa błędnie odczytała w tym miejscu III.

${ }^{9}$ Wszystkie dane wskazują, że chodzi o rok 1148 .

${ }^{10}$ Chodzi o Eugeniusza III, który był papieżem w latach 1145-1153.

${ }^{11}$ Konrad III cesarz niemiecki w latach 1138-1152.

${ }^{12}$ Bolesław (IV Kędzierzawy), książe mazowiecki w latach 1138-1173, po wygnaniu Władysława II senior w latach 1146-1173.

${ }^{13}$ Mieszko (III Stary), książę Wielkopolski od 1138 roku.

${ }^{14}$ Henryk (Sandomierski), książę sandomierski w latach 1148-1166.

${ }^{15}$ Władysław II Wygnaiec, książę-senior w latach 1138-1146, wygnany z Polski w 1146 roku umiera w 1159 roku.

${ }^{16}$ Z. Kozłowska-Budkowa odczytała w tym miejscu die gloriosissime Assumtionis sue. W innych kodeksach płockich jak np. Pericopae Evangelicae z XII wieku i również tutaj tzw. $e$ caudata jest wyraźnym skrótem dyphtongu ae lub oe i nie ma sensu transkrybować jej przez ę. Dalej termin glorissimae nie nosi skrótu więc nie ma żadnych podstaw do odczytywania go gloriosissimae jak Kozłowska-Budkowa. Chodzi oczywiście o dzień 15 sierpnia w którym celebrowano uroczystość Wniebowzięcia Maryi.

${ }^{17}$ Z. Kozłowska-Budkowa odczytała w tym miejscu tylko dignata pomijając zupełnie wyraźne w tekście est.

${ }^{18}$ Z. Kozłowska-Budkowa proponuje korektę na serenissimi, ale nie ma żadnych podstaw w rękopisie do takiego odczytania słowa. 
cham. nomine curatam e[ss]e innotu

iss[et]. factus est c[on]cursus populo[rum]

beata[m] Mariam cu[m] filio suo d[omi]no ih[es]u

$\mathrm{xr}[$ ist $]$ o. uociferatione maxima laudan

tium. qui $\mathrm{cu}[\mathrm{m}]$ patre et $\mathrm{sp}[$ irit $] \mathrm{u} \mathrm{s}[\mathrm{an}] \mathrm{c}[\mathrm{t}] \mathrm{o}$ [a]equa

lis ${ }^{19}$ uiuit et regnat $\mathrm{p}[\mathrm{er}]$ infinita $\mathrm{s}[\mathrm{e}] \mathrm{c}[\mathrm{u}] \mathrm{la}$

$\mathrm{s}[\mathrm{e}] \mathrm{c}[\mathrm{u}] \mathrm{lo}[\mathrm{rum}]$. AMEN.

Tłumaczenie tekstu na j. polski ${ }^{20}$ :

W roku 1148 od Wcielenia Pańskiego, w epakcie 28, konkurencji 4, w indykcji 11, w roku wspólnym, gdy w Rzymie przewodził papież Eugeniusz, cesarzem był Konrad, w Polsce zaś rządzili Bolesław, Mieszko i Henryk, a wypędzony został Władysław ${ }^{21}$, gdy natomiast diecezją płocką zarządzał odznaczający się godnym szacunku trybem życia biskup Aleksander, Najświętsza Maryja Panna w dniu swego najchwalebniejszego Wniebowzięcia, w obecności kustosza Azona, ${ }^{22} \mathrm{w}$ kościele płockim, przed prymą, zechciała łaskawie wyprostować i całkowicie uzdrowić młodą dziewczynę cierpiącą na skurcz ciała i utykającą na jedną nogę. A gdy wieść o tak wielkim cudzie dotarła do uszu najjaśniejszego księcia Bolesława, który wówczas przebywał w zamku, i dowiedział się wspomniany świętobliwy biskup Aleksander, że młoda dziewczyna imieniem Wojucha została uzdrowiona, zbiegli się tłumnie ludzie chwaląc tak głośno, jak mogli, Najświętszą Maryję wraz z Jej Synem, Panem Jezusem Chrystusem, który na równi z Ojcem i Duchem Świętym żyje i króluje przez nieskończone wieki wieków. AMEN.

${ }^{19}$ Z. Kozłowska-Budkowa odczytała w tym miejscu ęqualis.

${ }^{20}$ Tłumaczenie przejrzał i poprawił Pan prof. dr hab. J. Wojtczak-Szyszkowski. W tym miejscu pragnę wyrazić Panu Profesorowi serdeczne podziękowanie za okazaną pomoc. Poniżej dołączam thumaczenie A.J. Nowowiejskiego, Płock. Monografia historyczna, s. 38-39: „Rok od wcielenia pańskiego 1148, epakty 28, konkurentu 4, indykcji 11, roku pospólnego, kiedy w Rzymie zasiadał papież Eugeniusz, cesarzem był Konrad, w Polsce zasię panowali Bolesław, Mieszko i Henryk, po wygnaniu z kraju Włodzisława, gdy diecezją płocką zarządzał świętobliwego żywota biskup Aleksander, błogosł. Marya Panna w dzień przechwalebnego wniebowzięcia swego, wobec kustosza Azora, w kościele płockim, przed prymą, dzieweczkę skurczoną i napoły sparalizowaną raczyła podnieść i całkiem uzdrowić. To też, gdy wieść o tak wielkim cudzie doszła do uszu oświeconego księcia Bolesława, któren wtedy na zamku się znajdował, i kiedy mąż święty, rzeczony biskup Aleksander, dowiedział się, iż dzieweczka, Woincha imieniem, uzdrowiona została, zebrało się mnóstwo ludzi, głosem wielkim wychwalając błogosł. Maryę wraz z zej Synem, Panem Jezusem Chrystusem, który z Ojcem i Duchem Świętym w równości żyje i króluje w nieskończone wieki wieków. AMEN"

${ }^{21}$ A.J. Nowowiejski tłumaczy w tym miejscu błędnie Włodzisław, ale chodzi tutaj o Władysława Wygnańca a nie jakiegoś księcia o imieniu Włodzisław.

${ }^{22}$ A.J. Nowowiejski błędnie odczytał imię Azor, choć przy powiększeniu zdjęcia nie ma wątliwości, że to Azon. 
Opis drugiego cudu znajduje się poniżej w tej samej lewej kolumnie zewnętrznej w 31 wierszach i 6 wierszach od góry w następnej kolumnie, prawej. Oto tekst łaciński:

Eodem anno. nutu diuino, in teca uetustissima. gloriosis $\operatorname{sim}[\mathrm{a}] \mathrm{e}$ reliqui[a] $\mathrm{e}^{23}$ in sacrario $\mathrm{s}[\mathrm{un}] \mathrm{t}$ inuent[a] $\mathrm{e}^{24}$ : de corona uidelicet sal uatoris spinea. de inconsutili ei[us] tunica. de ap[osto]lis. petro. et paulo. de martirib[us]. Laurentio. et . Vincentio. exceptis alio[rum] s[an]c[t]o[rum] plusqua[m]. XL. pretiosissimis reliquíís. Has predictus uenerabilis Alexand[er] $\mathrm{ep}$ [is]c[opus]. deuotissime amplexatus. in ouo strutionis deaurato. hono rifice recondidit, et ne cui dein ceps mouendi eas facultas dare tur. anuli sui sigillo extrinsecus diligent[er] muniuit. Postea ue ro ante altare beat[a]e MARI[A]E $\mathrm{E}^{25}$ ide $[\mathrm{m}]$ ouum in catena ferrea laque ari picto affigi $\mathrm{p}[\mathrm{re}] \mathrm{c}[\mathrm{a}]$ epit, $\mathrm{q}[\mathrm{uo}] \mathrm{d}$ pictor eius. Guntherus. studiose exple uit. FRactus e[st] autem medi[us] caten[a]e anulus. et miru[m] in mo $\mathrm{du}[\mathrm{m}]$ cum reliquiis $\mathrm{s}[\mathrm{an}] \mathrm{c}[\mathrm{t}] \mathrm{o}[\mathrm{rum}]$ tam diu ouum e[st] lapsu[m]: donec a longe stans ad spectaculu[m] scolaris za charýas accureret. et in birro suo ouum cadens exciper[et].

$\mathrm{O}$ mira $\mathrm{d}[\mathrm{e}] \mathrm{i}$ potentia! O ueneran da $\mathrm{s}[\mathrm{an}] \mathrm{c}[\mathrm{t}] \mathrm{or}[\mathrm{um}]$ merita! Catena ruens ouu $[\mathrm{m}] \mathrm{n}[\mathrm{on}] \mathrm{co}[\mathrm{m}] \mathrm{minuit}$. caput excipie tis $\mathrm{n}$ [on] lesit. sed quasi $\mathrm{p}$ [er] manus

f. 239v: kolumna prawa

$\mathrm{s}[\mathrm{an}] \mathrm{c}[\mathrm{t}] \mathrm{o}[\mathrm{rum}]$ angelo[rum] collocata. sup[er] humero eius suauissime cecidit, ad laudem be atissim[a]e se[m]p[er] uirginis MARI[a] $\mathrm{e}^{26}$ et filii eius d[omi]ni n[ost]ri ih[es]u xr[ist]i, qui cu[m] d[e]o

\footnotetext{
${ }^{23}$ Z. Kozłowska-Budkowa odczytała w tym miejscu gloriosissime reliquię.

${ }^{24}$ Z. Kozłowska-Budkowa odczytała w tym miejscu invente

${ }^{25}$ Z. Kozłowska-Budkowa odczytała w tym miejscu Beatę Marię.

${ }^{26}$ Z. Kozłowska-Budkowa odczytała w tym miejscu Beatissimę semper Virginis Marię.
} 
patre et $s p[$ irit $] \mathrm{u} s[\mathrm{an}] \mathrm{c}[\mathrm{t}] \mathrm{o}$ equal[is] uiuit et reg nat $\mathrm{p}[\mathrm{er}]$ infinita sec[u]la sec[u]lo[rum]. AMEN.

Tłumaczenie na język polski ${ }^{27}$ :

W tym samym roku, za Bożym zrządzeniem, w bardzo starej szkatułce, $\mathrm{w}$ zakrystii, zostały znalezione najczcigodniejsze relikwie: a mianowicie z korony cierniowej Zbawiciela, z jego całodzianej tuniki, z ciał Apostołów Piotra i Pawła, z ciał męczenników Wawrzyńca i Wincentego oprócz bardzo cennych relikwii innych świętych więcej niż czterdziestu. Relikwie te, wspomniany czcigodny biskup Aleksander najpobożniej objąwszy złożył ze czcią w pozłacanym jaju strusim, aby zaś nikt nie miał później możliwości ich zabrania, zabezpieczył je pieczęcią swojego pierścienia na zewnątrz. Następnie zaś polecił przytwierdzić to samo jajo do stropu na żelaznym łańcuchu przed ołtarzem Najświętszej Maryi, co starannie wykonał jego malarz Gunterus. Złamało się jednak środkowe ogniwo łańcucha, ale w przedziwny sposób jajo wraz z relikwiami świętych tak długo powoli się zsuwało, aż stojący z daleka i patrzący na to zjawisko uczeń Zachariasz podbiegł i pochwycił spadające jajo w kaptur swojej opończy. O przedziwna mocy Boża! O czcigodne zasługi świętych! Spadający łańcuch nie rozbił jaja, nie zranił też głowy chwytającego je, ale jakby rękami aniołów umiejscowiony spadł łagodnie na jego ramię, na chwałę Najświętszej zawsze Dziewicy Maryi i Jej Syna, naszego Pana Jezusa Chrystusa, który na równi z Bogiem Ojcem i Duchem Świętym żyje i króluje przez nieskończone wieki wieków. AMEN.

Tekst łaciński rozpoczyna się w pierwszym zapisie literą „A” a w drugiej „E” $\mathrm{w}$ formie inicjału w kolorze czarnym. Obydwie notatki pisane były jednocześnie tą samą ręką i na liniach zaznaczonych rylcem, dużym pismem, stylem odbiegającym zarówno od poprzedzających je czytań z tekstów św. Augustyna, jak też następującego po nich opisu liturgii w katedrze płockiej oraz od pozostałych części

${ }^{27}$ Tłumaczenie przejrzał i poprawił Pan prof. dr hab. J. Wojtczak-Szyszkowski. W tym miejscu pragnę wyrazić Panu Profesorowi serdeczne podziękowanie za okazaną pomoc. Poniżej przytaczam thumaczenie A. J. Nowowiejskiego, Płock. Monografia historyczna, s. 39: „Tegoż roku, za wolą bożą znaleziono w skarbcu kościelnym w oprawie bardzo starej przesławne relikwie, a mianowicie: wieńca cierniowego Zbawiciela, nieszytej jego tuniki, apostołów Piotra i Pawła, męczenników Wawrzyńca i Wincentego, okrom innych relikwii świętych przeszło 40. One czcigodny Aleksander biskup najpobożniej ucałowawszy, w wyzłoconem jaju strusiem ze czcią umieścił, a iżby nikt w przyszłości nie mógł ich ruszyć stamtąd, pierścienia swego sygnetem na zewnątrz starannie zabezpieczył. Potem zasię przed ołtarzem błog. Maryi Panny toż jajo na łańcuchu żelaznym u sufitu malowanego zawiesić kazał, co malarz jego Gunter starannie wykonał. Pękło zasię środkowe ogniwo łańcucha, atoli, rzecz dziwna, tak długo spadało z relikwiami świętych, że przyglądający się zdala szkolarz Zacharjasz zdążył przybiegnąć i schwytać w swój biret spadające jajo. O przedziwna mocy boża! O czcigodne zasługi świętych! Łańcuch spadający jaj nie stłukł, głowy chwytającego nie zranił, ale jak gdyby rękoma świętych spuszczony na ramionach jego spoczął lekuchno, na chwałę najśw. zawsze dziewicy Maryi i Syna jej, Pana naszego Jezusa Chrystusa, który z Bogiem Ojcem i Duchem Świętym równy żyje i króluje w nieskończone wieki wieków. AMEN”. 
kodeksu. Z. Kozłowska-Budkowa określa ten styl jako „silący się na ozdobność o cechach wskazujących na pierwszą połowę XII wieku"28. Warto podkreślić fakt, że teksty zostały zapisane na liniach zaznaczonych rylcem, co dowodzi, iż liniowanie kart pergaminowych wprowadzono w kodeksach już w połowie XII wieku a nie jak to się niekiedy błędnie twierdzi, dopiero w XIII wieku. Nasze zapiski są spisane na liniach wykonanych rylcem i pochodzą z 1148 roku.

W pierwszym wierszu pierwszej zapiski litery są wydłużone i przypominają kratowe pismo dyplomatyczne, druga natomiast rozpoczyna się już stylem normalnym. Ponieważ obie notatki zostały zapisane prawdopodobnie w tym samym czasie i tą samą ręką więc musiały powstać już po drugim cudzie związanym z odkryciem relikwii i chęcią umieszczenia ich $\mathrm{w}$ strusim jaju pod sufitem katedry płockiej przed ołtarzem Maryi. Nie wiemy niestety kiedy dokładnie ten drugi cud miał miejsce, ale pamiętając, że pierwszy zdarzył się w święto Wniebowzięcia Maryi, czyli 15 sierpnia 1148 roku, to drugi musiał mieć miejsce po nim w tym samym roku, czyli pomiędzy sierpniem a końcem roku 1148. Sam opis oczywiście niekoniecznie musiał powstać jeszcze w tym samym roku, ale jego żywy charakter i odzew jaki wywołały te wydarzenia w lokalnym środowisku kościelnym wskazują, że notatki sporządzono krótko po samych wydarzeniach, czyli najprawdopodobniej w samym 1148 roku lub krótko potem, na początku 1149 roku.

Płockie zapiski są najstarszymi zabytkami piśmiennymi o cudach powstałymi na ziemiach polskich, które zachowały się do naszych czasów. W sensie formy nie należą one do znanego i rozpowszechnionego w średniowieczu gatunku literackiego miracula, które posiadały rozbudowaną, często fantazyjną narrację i stawiały sobie za cel przekazać pouczenia moralne. W naszych zapiskach tego typu elementów zupełnie brakuje, za to mamy suchy i krótki zapis historycznych wydarzeń, które rzeczywiście musiały mieć miejsce w ówczesnej katedrze w Płocku w 1148 roku. Z. Kozłowska-Budkowa podkreśla formalne podobieństwo pomiędzy pierwszą zapiską płocką a zapiską krakowską z 1166/1167 roku o zamianie jednej ze wsi pomiędzy biskupem Gedką a księżną Marią czy zapiską wrocławską z 1139 roku o nadaniu kaplicy św. Michała przez biskupa Roberta podsumowując: „Ze względu na formę, możnaby cuda płockie umieścić śmiało w wydawnictwie dyplomatycznym, podczas gdy treść kazałaby je odnieść raczej do zbioru hagiograficznego" 29 . Można jednak mieć wątpliwości co do drugiej części tej wypowiedzi. Zapiska płocka nie jest typowym tekstem hagiograficznym, który opisuje kult jakiegoś świętego i cuda, które przez jego pośrednictwo się dokonały. Pierwsza wzmianka dotyczy cudu, który dokonał się w święto Wziebowzięcia Maryi i za jej wstawiennictwem. Nie posiada ona jednak typowych elementów miracula: modlitwy, prośby o wstawiennictwo itp., ale cud dokonuje się spontanicznie, przez samo przyjście owej młodej dziewczyny o imieniu Wojucha do katedry płockiej. Autor notatki wyraźnie podkreśla, że Maryja sama w swoje święto zechciała ją uzdrowić (beata Maria Virgo in die glorissimae assumtionis suae [...] iunenculam contractam et semipedem dignata est erigere et penitus sanare). Brakuje również

${ }^{28}$ Por. Z. Kozłowska-Budkowa, Płockie zapiski z 1148 r., s. 342-343.

${ }^{29}$ Tamże, s. 343. 
elementów fantazyjnych, które często pojawiają się w opisach wczesnochrześcijańskich i średniowiecznych tego typu cudów. Bardzo ważna jest też dokładna informacja o tym kiedy to się wydarzyło, co również odróżnia ją od narracji o innych cudach. Autor notatki pierwszej podaje bardzo dokładne dane $\mathrm{z}$ historii kościelnej i państwowej: za pontyfikatu papieża Eugeniusza III (presidente Rome papa Eugenio), za rządów cesarza Konrada (imperante Cunrado), za panowania w Polsce Bolesława, Mieszka i Henryka po wypędzeniu Władysława Wygnańca (in Polonia autem regnantibus Bolezlao, Mysecone et Hinrico fugatoque de terra Wladizlao), gdy diecezją płocka kierował czcigodnego życia biskup Aleksander (procurante vero plocensem diocesim venerabilis vite Alexandro episcopo). Co więcej, autor podkreśla, że gdy wydarzył się cud, książę Bolesław przebywał w tym czasie, czyli 15 sierpnia 1148 roku w grodzie w Płocku (qui tunc in castro aderat). Pierwszy cud dokonał się w dzień święta Wniebowzięcia Maryi (in die glorissimae Assumtionis suae) i taka ilość nagromadzonych konkretnych postaci i dokładnych danych historycznych czyni z naszych zapisków wyjątkowe źródło i świadczy o tym, że autorowi zależało bardzo na przekazaniu wiarygodnego świadectwa historycznego dla potomnych. Nie ulega wątpliwości, że notatka musiała powstać w lokalnym skryptorium w Płocku w czasie spisywania kodeksu biblijnego, co potwierdza, iż w tym czasie istniała w Kościele płockim duża świadomość historyczna. Fakt, że zapiski nie zostały umieszczone na marginesie kodeksu, ale wpisane w ciąg kolumn przepisywanego w tym czasie tekstu biblijnego potwierdza wyraźnie, że Biblia Płocka została przepisana w lokalnym skryptorium a nie przywieziona z kraju Mozy, gdyż tam takie zapiski z pewnością by nie powstały. A to oznacza, że w połowie XII wieku istniało w Płocku skryptorium w którym przepisywano księgi biblijne i liturgiczne na użytek liturgii katedralnej i lokalnej szkoły. Przypuszczenia, że kierownikiem owego skryptorium był wspominany w pierwszej zapisce Azo są niemożliwe do weryfikacji.

Zapiski umieszczono prawdopodobnie na polecenie samego biskupa Aleksandra lub z inicjatywy kogoś z jego mozańskiego kręgu obecnego w tym czasie w Płocku, np. kustosza Azo. To oni przywieźli do Płocka znad Mozy większą świadomość historyczną i opisali historię cudów, osadzając ją w bardzo szerokim i dokładnym kontekście historycznym. Autor podkreśla również obecność w katedrze naocznego świadka cudu, Azona, który był kustoszem w katedrze płockiej (presente custode Azone in ecclesia plocensi ante primam). Z. Kozłowska-Budkowa przypuszcza, że kustosz Azo wspomniany w pierwszym opisie i ten wzmiankowany w księdze opactwa w Lubiniu (MPH V, s. 572), to jedna i ta sama osoba, a sam Azo byłby również autorem zapisków płockich. A ponieważ mnisi lubińscy pochodzili z klasztoru św. Jakuba z Liège lub z Gembloux, ich związki z płockim Azo potwierdzałyby jego leodyjskie pochodzenie, a charakter zapisków zdradzałby rękę wyszkoloną gdzieś na Zachodzie. ${ }^{30}$ A Vetulani nie zgadza się taką opinią podkreślając, że Azon był zapewne kierownikiem lokalnego skryptorium

${ }^{30}$ Tamże, s. 347. 
i kustoszem katedry, a nie zwykłym skrybą. ${ }^{31}$ Trudno rozstrzygnąć kto ma rację. Wspomnienie jego imienia wskazuje na to, że nawet jeśli nie dokonał on sam materialnie tego zapisu, to jako kustosz katedry mógł zlecić jego wykonanie. Sam temin custos nie oznaczał kierownika skryptorium, jak chce Vetulani, ale duchownego, który otaczał szczególną troską katedrę płocką. Tytuł kustosza katedry płockiej przetrwał aż do połowy XX wieku. Nie ma też bezpośrednich dowodów na to, że płocki i lubiński Azo to ta sama osoba, a samo imię było bardziej popularne w tym czasie we Włoszech, choć znane również w kraju Mozy.

W pierwszym opisie młoda dziewczyna Wojucha cierpiąca na skurcz ciała i utykając na jedną nogę (iuvencula contracata et semipede) zostaje nagle wyprostowana i całkowicie uzdrowiona (erigere et penitus sanare). Gdy informacja o cudzie dotarła do uszu księcia Bolesława i biskupa Aleksandra (cumuque rumor tanti miraculi ad aures serenissi ducis Bolezlai [...] viorque snacto prefato episcopo Alexandro) udali się oni zapewne do katedry i potwierdzili uzdrowienie młodej dziewczyny właśnie o imieniu Wojucha. Gdy wieść rozeszła się po całym Płocku, zbiegł się lud (factus est concursus populorum) do katedry, aby oddać cześć Maryi i całej Trójcy Świętej.

W drugim opisie znajdujemy również kilka ciekawych elementów. Drugi cud wydarzył się w tym samym roku (eodem anno), czyli po sierpniu 1148. Wcześniej w zakrystii katedralnej (in sacrario) znaleziono bardzo starą szkatułę lub po prostu skrzynię (teca vetustissima) z relikwiami, co wskazuje na fakt, iż były one przechowywane w katedrze wcześniej i oddawano im tam kult. Z. Kozłowska-Budkowa przypuszcza, że te relikwie mogły wręcz pochodzić z XI wieku, czyli z czasów powstania biskupstwa płockiego, ale pewności tutaj nie mamy. Relikwie był zebrane razem w teca vetustissima, a teraz zostały ponownie odnalezione. Dziwić może fakt, że w średniowieczu, w którym przecież tak wielką wagę przywiązywano w Kościele do kultu relikwii, nikt w Płocku nie wiedział o istnieniu wcześniejszego zbioru różnych relikwii i przypadkowo je odnaleziono w roku 1148. Jeśli nową katedrę konsekrowano rzeczywiście 1 października 1144 roku, co potwierdzają tzw. Wspominki płockie i sochaczewskie (MPH III, s. 119), to wygląda na to, że do 1148 roku nic nie wiedziano o tych relikwiach. Prawdopodobnie, choć konsekracja katedry płockiej odbyła się w 1144 roku, to jednak nadal były prowadzone w niej jakieś prace budowlane i przy ich okazji odnaleziona została owa stara skrzynia z relikwiami. To, że katedra nie została jeszcze całkowicie ukończona potwierdza fakt, że słynne drzwi z brązu zamówione przez biskupa Aleksandra w Magdeburgu zostaną do niej sprowadzone później, bo w latach 1152-1154 $4^{32}$, a także wzmianka o obecności malarza Gintera pochodzącego z Magdeburga lub kraju Mozy, ojczyzny biskupa Aleksandra. Przypadkowo odkryto skrzynię z następującymi relikwiami: korony cierniowej Chrystusa (de corona videlicet Salvatoris spinea), fragment całej tkanej tuniki Zbawiciela (de

${ }^{31}$ Por. A. Vetulani, Średniowieczne rękopisy płockiej biblioteki katedralnej, „Roczniki Biblioteczne", 7 (1963) z. 3-4, s. 417.

${ }^{32}$ Takiego zdania jest R. Knapiński, Credo Apostolorum w romańskich Drzwiach Płockich, Płock 1992. 
incinsutili eius tunica), z kości Apostołów Piotra i Pawła (de apostolis petro et pauolo), męczenników Wawrzyńca i Wincentego (de martiribus Laurentio et Vincentio) a także ponad 40 innych świętych (exceptis aliorum sanctorum plusquam $X L$ ). Trudno wyjaśnić pochodzenie relikwii dotyczących osoby Chrystusa, gdyż w średniowieczu były bardzo liczne i część pewnie była fałszywa. Natomiast relikwie Apostołów Piotra i Pawła były bardzo popularne w Europie i każdy znaczący kościół chciał je posiadać, zwłaszcza świątynie pod ich wezwaniem. W Polsce pojawiają się one zapewne już w XI wieku, gdyż mamy ślady ich obecności w katedrze poznańskiej zbudowanej właśnie pod ich wezwaniem a także w Kruszwicy i Kaliszu. Z Leodium docierają najprawdopodobniej do Płocka relikwie św. Wawrzyńca, gdyż istniał tam w XI wieku klasztor pod jego wezwaniem ${ }^{33}$. Być może podczas swojej pierwszej wyprawy misyjnej na Mazowsze benedyktyni z Leodium ufundowali jeszcze w XI wieku kościół pw. św. Wawrzyńca w Płocku, wzmiankowany w falsyfikacie mogileńskim z 1065 roku i choć brakuje nam elementów do ostatecznej weryfikacji, to jednak jest prawdopodobne, że początkowo katedra płocka nosiłaby właśnie wezwanie św. Wawrzyńca. Zmiany owego titulus ecclesiae na Wniebowzięcie Maryi Panny dokonano być może na przełomie XI -XII wieku lub uczyniłby to biskup Aleksander z Malonne, wielki czciciel Maryi. Jeśli zaś chodzi o relikwie męczennika, św. Wincentego, to w średniowieczu było wielu świętych czczonych pod tym imieniem. Prawdopodobnie pisarz miał na myśli Wincentego diakona, zamęczonego w Walencji, którego kult był najbardziej rozpowszechniony w tym czasie a jego relikwie czczono w katedrze wrocławskiej w XI wieku ${ }^{34}$. Dotarłyby więc one do Płocka z Wrocławia lub bezpośrednio z Leodium.

Po odkryciu relikwii biskup Aleksander nakazał, aby ze czcią umieszczono je w wyzłoconym strusim jaju i opieczętował swoim pierścieniem (Has predictus uenerabilis Alexander episcopus, deuotissime amplexatus, in ouo strutionis deaurato honorifice recondidit, et ne cui deinceps mouendi eas facultas daretur anuli sui sigillo extrinsecus diligenter muniuit). Używanie wyzłoconego jaja strusiego jako relikwiarza jest potwierdzone również w innych miejscach Polski w tym czasie, choćby w Krakowie, gdzie w skarbcu katedry wawelskiej znajdują się zarówno skrzyneczki na relikwie, jak też dwa strusie jaja (MPH I, s. 377). Następnie wspomniany biskup, wielki czciciel Matki Bożej polecił zawiesić cały relikwiarz w formie wyzłoconego jaja strusiego przed ołtarzem Matki Bożej na żelaznym łańcuchu pod nowo wymalowanym sufitem katedry płockiej (Postea uero ante altare beatae Mariae idem ouum in catena ferrea laqueari picto affigi precaepit, quod pictor eius, Guntherus, studiose expleuit). Wtedy właśnie wydarzył się drugi cud: podczas zawieszania jaja strusiego z relikwiami, przerwało się jedno z ogniw łańcucha (Fractum est autem medius catenae annulus) i jajo zaczęło spadać ku ziemi (et mirum in modum cum reliquiis sanctorum tam diu ouum est lapsum), gdy przyglądający się z daleka scholar Zachariasz pochwycił je w swoją

${ }^{33}$ Por. Cz. Deptuła, Krag kościelny płocki w połowie XII wieku, ,Roczniki Humanistyczne”, 8 (1959) z. 2, s. 5-122; tenże, Kościót płocki w XII wieku, „Studia Płockie”, 3 (1975) s. 67-84.

${ }^{34}$ Por. Kozłowska-Budkowa, Płockie zapiski z 1148 r., s. 346. 
opończę (donec a longe stans ad spectaculum scolaris zacharýas accureret et in birro suo ouum cadens exciperet). Skryba wychwala następnie moc Bożą i zasługi świętych, dzięki którym coś podobnego się wydarzyło. Spadający łańcuch nie zmiażdżył jaja, ani nie zranił głowy Zachariasza, ale w cudowny sposób zsunął się delikatnie po jego ramieniu na ziemię niesiony jakby rękami aniołów (Catena ruens ouum non comminuit caput excipietis non lesit, sed quasi per manus sanctorum angelorum collocata super humero eius suauissime cecidit).

A wszystko to stało się ku chwale Najświętszej zawsze Dziewicy Maryi i jej Synowi, naszemu Panu Jezusowi Chrystusowi, który z Bogiem Ojcem i Duchem Świętym żyje i króluje na wieki wieków. Obydwa zapiski kończą się w ten sam sposób, czyli oddaniem chwały Maryi i całej Trójcy Świętej. Potwierdzają one, że biskup Aleksander skutecznie przeszczepił z kraju Mozy kult Maryi do Płocka, a przez to na całe Mazowsze. Obydwa opisy służyły bez wątpienia umocnieniu kultu Maryi: obydwa cuda wydarzyły się w katedrze płockiej pw. Maryi, pierwszy - uzdrowienie Wojuchy miał miejsce dokładnie w dzień Wniebowzięcia Maryi, a drugi cud przed jej ołtarzem. Wzmianka o uczniu (łac. scholar) Zachariaszu potwierdza, że w połowie XII wieku istniała już w Płocku szkoła przykatedralna do której uczęszczał. Warto również podkreślić, że nasze zapiski wyraźnie potwierdzają, że w średniowieczu w Płocku a pewnie też w kraju Mozy, na długo przed ogłoszeniem dogmatu, celebrowano już święto Wniebowzięcia Maryi.

Słowa kluczowe: zapiski płockie, Biblia Płocka, cuda

\section{BIBIOGRAFIA}

Bershon Mathias, Księgozbiór katedry płockiej, Warszawa 1899.

Brzeziński Daniel, Leszkiewicz Bartosz, Zapiski liturgiczne w kodeksie Biblii Płockiej z

XII wieku. Studium źródłoznawcze i edycja tekstu, Płock 2005.

Deptuła Czesław, Krąg kościelny płocki w połowie XII wieku, „Roczniki Humanistyczne", 8 (1959) z. 2, s. 5-122.

Deptuła Czesław, Kościół płocki w XII wieku, Studia Płockie 3 (1975) s. 67-84.

Knapiński Ryszard, Credo Apostolorum w romańskich Drzwiach Płockich, Płock 1992.

Kozłowska-Budkowa Zofia, Płockie zapiski o cudach z 1148 r., „Roczniki Historyczne”, 44 (1930) s. 341-348.

Nowowiejski Antoni Julian, Płock. Monografia historyczna, Płock 1930.

Vetulani Adam, Średniowieczne rękopisy płockiej biblioteki katedralnej, „Roczniki Biblioteczne", 7 (1963) z. 3-4, s. 417.

Wolf Adam, Projekt instrukcji wydawniczej dla źródeł pisanych do połowy XVI wieku, „Studia Źródłoznawcze”, 1 (1957) s. 155-181. 


\title{
THE NOTES OF THE MIRACLES OF 1148 IN THE BIBLE OF PLOCK
}

\begin{abstract}
Summary
The famous notes in the Bible of Płock are the oldest documented written texts created on the Polish territory. A great deal of false information which grew up around them was repeated by the next generations of historians without proper research. First, there is no indication that, according to Berhson, the cards 239v and 240R-v in the Bible of Płock were left blank, where later our notes were made. Secondly, the notes of the miracles and the liturgy of the cathedral were not made in the margins of the Code, which is often incorrectly presented in different studies, but in two columns, like the text of the Bible before and after them. The notes of the miracles were made by the same scribe, but in a different handwriting than the entire Code: either the Code was created in 1148 and the notes of the miracles were added later or the Code was created at the same time when the miracles happened and the notes were included at the time of writing the Code or the Code was created later and the notes were also added later. There are many indications that the notes of the miracles were included during the preparation of the Code. In any case, the Code was probably created in 1148 or about that date and a vivid description of the miracles seems to indicate that the notes were made shortly after the events themselves, or after 15 August 1148 or early 1149 . The first miracle was the healing of a woman, named Wojuchna, of paralysis on the feast of the Assumption of the Blessed Virgin Mary on 15 August 1148, and the other one concerned the relics placed in an ostrich egg under the ceiling of the Cathedral of Płock and saving them miraculously when they fell down. Since the notes were not made in the margins the Code, but placed in a string of columns of the biblical text which was copied then, it confirms clearly that the Bible of Płock was copied in the local scriptorium. This means that in the middle of the twelfth century there existed a scriptorium in Płock, where biblical and liturgical books were copied for the cathedral liturgy and the local school. The notes were probably made by order of the then Bishop of Płock, Alexander of Malonne and it is possible that they were made by the director of the scriptorium, mentioned in the first note-Azo, though due to missing elements, it cannot be confirmed. The other note mentioning a scholar Zacharias confirms the existence of a school attached to the Cathedral in Płock in the middle of the twelfth century.
\end{abstract}

Keywords: the notes of Płock, the Bible of Płock, miracles

Translated by Aneta Kiper 